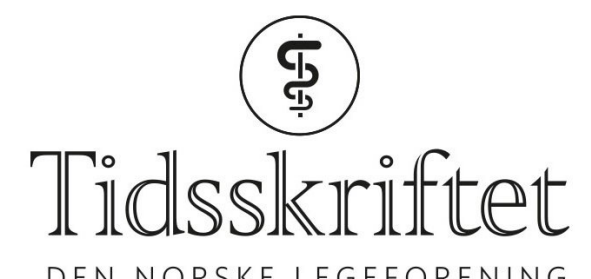

DEN NORSKE LEGEFORENING

\title{
Selvmord under en pandemi
}

LEGELIVET

\section{ERLEND HEM}

E-post: erlend.hem@medisin.uio.no

Erlend Hem er instituttsjef ved Legeforskningsinstituttet og professor i atferdsmedisin ved Universitetet i Oslo.

Selvmordsraten kan ha gått ned under koronaen. Vi kan frykte en økning når pandemien er over.

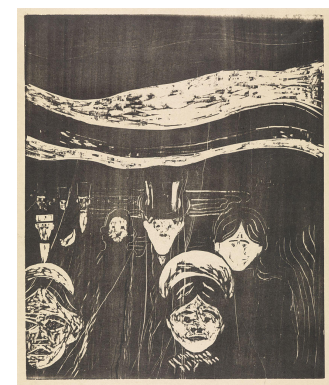

"Angst» av Edvard Munch. Foto:

Nasjonalmuseet / Dag Andre

Ivarsøy

Det har vært flere reportasjer i mediene om psykiske problemer og $ø \mathrm{kt}$ forekomst av selvmordstanker i befolkningen i forbindelse med koronapandemien. Dette bygger blant annet på informasjon fra telefontjenester som Kirkens SOS og Mental Helse. Det er utvilsomt mange som sliter. Det synes imidlertid ikke å ha vært noen økning i antall mennesker med selvmordsforsøk innlagt i Oslo universitetssykehus det første året etter mars 2020 (Ingvild Strand Hovland, personlig meddelelse).

\section{Selvmordsraten under kriser}

Når et land er utsatt for trusler, for eksempel i form av krig eller terror, mobiliseres krefter for å overleve, og selvmordsraten går gjerne ned. Det er sannsynlig at det samme kan være tilfellet ved en pandemi, hvor en annen ytre fare truer landet.

Det er gjort studier av hvordan selvmordsraten har utviklet seg under koronapandemien. Forekomsten av selvmord i Norge i de tre første månedene av pandemien (mars-mai 2020) var noe lavere enn i de foregående år, men innenfor usikkerhetsmarginene (1).

I en stor internasjonal studie publisert i april 2021 undersøkte man forekomsten av selvmord i 33 områder i 21 land i perioden 1.1.2016-31.10.2020 (2). De fant at det var en nedgang i ti av områdene, mens det ikke var noen endringer i de øvrige. Muligens kan nedgangen være midlertidig og at man vil se en $ø$ kning i selvmordsraten med tida (3). 


\section{Selvmordsatferd blant helsepersonell}

Selvmord blant leger i Norge har vært grundig undersøkt (4). Vi har imidlertid ikke tall etter år 200o, og Legeforskningsinstituttet planlegger en oppfølgingsstudie for å undersøke utviklingen de siste 20 år. Hvis vi antar at raten er dobbelt så høy som i den generelle befolkning, vil den for leger være ca. 24/10o ooo/år. Dersom vi regner at det er 40 ooo leger i Norge (tallet er noe lavere, brukes her som eksempel), skulle vi forvente ca. ti selvmord blant leger i Norge årlig. Det gir et for lite tallmateriale til å si noe sikkert om endringer fra et år til annet. Det kan tenkes at det har vært flere i en storby i en periode, for det er ikke uvanlig at man kan få en opphopning av selvmord i en gruppe i en bestemt periode (mulig smitteeffekt).

Mye tyder på at mange fastleger sliter. Mest sannsynlig er arbeidssituasjonen en viktig årsak til dette, mens covidpandemien har mindre betydning. Det er indikasjoner på at intensivpersonellet i Norge, som har de tyngste oppgavene med covidpasientene, ikke har mer psykiske problemer enn før (Øivind Ekeberg, personlig meddelelse). Det blir viktig å følge utviklingen nøye i tida som kommer.

\section{LITTERATUR:}

1. Qin P, Mehlum L. National observation of death by suicide in the first 3 months under COVID-19 pandemic. Acta Psychiatr Scand 2021; 143: 92-3. [PubMed][CrossRef]

2. Pirkis J, John A, Shin S et al. Suicide trends in the early months of the COVID-19 pandemic: an interrupted time-series analysis of preliminary data from 21 countries. Lancet Psychiatry 2021; 8: S2215-0366(21)ooo91-2. [PubMed][CrossRef]

3. Tanaka T, Okamoto S. Increase in suicide following an initial decline during the COVID-19 pandemic in Japan. Nat Hum Behav 2021; 5: 229-38. [PubMed][CrossRef]

4. Hem E. Selvmord blant leger. Tidsskr Nor Legeforen 2015; 135:305. [PubMed][CrossRef]

Publisert: 28. juni 2021. Tidsskr Nor Legeforen. DOI: 10.4045/tidsskr.21.0442

(C) Tidsskrift for Den norske legeforening 2020. Lastet ned fra tidsskriftet.no 